\title{
Effect of Sulphur Application on the Availability of some Nutrients in Egyptian Soils
}

\author{
A.M. El-Kholy, O.M. Ali, E.M. El-Sikhry and A.I. Mohamed \\ Soil and Water Department, Faculty of Agriculture, Suez \\ Canal University, Ismailia, Egypt.
}

\begin{abstract}
A INCUBATION experiment was carried out to study the effect of different size and application rates $(0,0.51 .0,2.0 \%)$ of elemental Sulphur (S) on $\mathrm{pH}, \mathrm{EC}$, soluble sulphate and Extractable $\mathrm{P}, \mathrm{K}, \mathrm{Fe}$ and $\mathrm{Mn}$ in seven soils collected from different sites in Egypt which differed in physical, chemical characteristics and mineralogical composition. Three size of S were used, fine $50 \mu \mathrm{m}$, coarse $250 \mu \mathrm{m}$ and very coarse $>250 \mu \mathrm{m}$ and the moisture content was kept at field capacity by daily addition of distilled water. Sulfur application up to $2 \%$ level caused a significant decrease in soil $\mathrm{pH}$ values relative to the control treatment. These reductions were more pronounced in case of sandy soils. The soil $\mathrm{pH}$ values were lower in the investigated soils amended with the fine particle size of $S$ compared with the coarse and very coarse particle size of $\mathrm{S}$, respectively. Sulfur application also significantly increased the EC, the solubility of sulphate, $\mathrm{P}, \mathrm{K}, \mathrm{Fe}$ and $\mathrm{Mn}$ in the soils during the period of incubation.
\end{abstract}

Keywords: Sulphur, Incubation, Phosphorous, Potassium, Iron, Manganese

The horizontal expansion of agricultural soils in Egypt depends on the reclamation of new lands which are mainly calcareous soils. Most of these soils are dominated in the north western coastal zone and Sinai Peninsula. The majority of these soils are characterized by alkaline $\mathrm{pH}$, high calcium carbonate content and subsequently reduction in soil macro - and micronutrient availability, which adversely affects plant growth. For example nitrogen, phosphorus, and micronutrients are strongly affected by the alkaline nature of these soils, which cause losses of large amounts of nitrogen by volatilization, phosphorus by fixation, and iron and manganese by precipitation to their oxide and hydroxide forms. Application of $\mathrm{S}$, as a soil amendment, is a common practice worldwide to improve the physical and chemical properties of calcareous soils, in addition to other type of soils. Under optimal condition, $\mathrm{S}$ is converted into sulphuric acid within a few weeks by soil microorganism (Balwan et al., 2006). The sulphuric acid then acts to reduce the relatively high $\mathrm{pH}$ values of the calcareous soils and dissolve native lime (Ammal et al., 2000). In turn, released $\mathrm{Ca}$ would replace the sodium on the exchange complexes and also react with produced sulphate to form gypsum. Accordingly, gypsum formation in these soils is largely controlled by accelerating the oxidation 
mechanism, (Reda and Modaihsh, 1990). The acidity produced during S oxidation increases the availability of nutrients such as $\mathrm{P}, \mathrm{Mn}, \mathrm{Mg}, \mathrm{Cu}, \mathrm{Fe}$ and $\mathrm{SO}_{4}$ in soils, which may enhance the chemical and physical characteristics of these alkaline soils.

The rate of S oxidation depends on several factors such as $\mathrm{S}$ particle size, soil moisture content, organic matter content, microbial populations and temperature (Susana et al., 2013). Sulfur is one of the essential nutrients for plant nutrition, and without sufficient $S$, plants cannot achieve optimum grown and yield, because $\mathrm{S}$ play a prominent role in plant physiology. It is generally added to the soil as organic $\mathrm{S}$ or an associated anion $\mathrm{SO}_{4}{ }^{2-}$ with different cations in the fertilizers such as potassium sulphate, ammonium sulphate or calcium sulphate in super phosphate (Morris, 1992). Nowadays, there is a great trend to use the highly concentrated fertilizers, such as urea or ammonia, which are free from $\mathrm{S}$. Thus, the addition of $\mathrm{S}$ as a fertilizer will be important and necessary in the future. On the other hand, Saudi Arabia produces about 1.4 million tons of elemental S annually (Sadiq, 1985). So, elemental S is available and less costly material for amending calcareous soils of Egypt to increase the availability of certain nutrient elements, as well as improving some physical properties of these soils and other types of soils.

The aim of this study is to evaluate the effect of different sizes of elemental S on the availability of some macro and micronutrients in different Egyptian soils.

\section{Material and Methods}

Seven surface soil samples $(0-30 \mathrm{~cm})$ were varied in physical and chemical characteristics and collected from different sites to represent Egyptian soil types. The first group represented highly calcareous soils was taken from Ras Sudr, Wady El Arish, South and North of Sinai Governorates and Maryut from west of Cairo-Alexandria Desert Road, respectively. The second soil group represented alluvial soils was taken from Sakha and El-Mahsama. The third soil group represented sandy soils was taken from El-Manaief and Faculty Farm of Agricultural Suez Canal University, Ismailia. The physical and chemical properties of these soil samples were determined according to Page et al. (1982). Analytical data of the investigated soils were shown in Table 1.

An incubation experiment was carried out to study the effect of different size of elemental $\mathrm{S}$ at application rates of $0,0.51 .0,2.0 \%$ on $\mathrm{pH}, \mathrm{EC}$, soluble sulphate and Extractable P, K, Fe and $\mathrm{Mn}$ in the studied soils. Three size of S were used; fine $50 \mu \mathrm{m}$, coarse $250 \mu \mathrm{m}$ and very coarse $>250 \mu \mathrm{m}$. From each soil under investigation, $100 \mathrm{~g}$ soil sample was taken and mixed thoroughly with different $\mathrm{S}$ treatments and moistened with distilled water up to the field capacity. These soil samples were incubated according to Mc Cready and Krouse (1982) for five weeks at $30^{\circ} \mathrm{C}$. The moisture content was kept at field capacity by daily addition of distilled water. After the incubation period, soil samples were collected and analyses.

Egypt. J. Soil Sci. 53, No. 3 (2013) 
TABLE 1. Some physical and chemical properties of investigated soils.

\begin{tabular}{|c|c|c|c|c|c|c|c|}
\hline \multirow[b]{3}{*}{ Soil parameter } & \multicolumn{7}{|c|}{ Soils } \\
\hline & \multicolumn{3}{|c|}{ calcareous } & \multicolumn{2}{|c|}{ Alluvial } & \multicolumn{2}{|c|}{ Sandy } \\
\hline & $\begin{array}{l}\text { Ras } \\
\text { Sudr }\end{array}$ & $\begin{array}{c}\text { Wady } \\
\text { El-Arish }\end{array}$ & Maryut & Sakha & $\begin{array}{c}\text { El- } \\
\text { Mahsama }\end{array}$ & $\begin{array}{c}\text { El- } \\
\text { Manaief }\end{array}$ & $\begin{array}{c}\text { Faculty } \\
\text { Farm }\end{array}$ \\
\hline Sand, \% & 82.6 & 79.9 & 60.6 & 15.0 & 68.6 & 86.5 & 91.2 \\
\hline Silt, $\%$ & 8.40 & 8.76 & 15.4 & 33.9 & 21.6 & 11.2 & 8.25 \\
\hline Caly, \% & 7.00 & 11.3 & 24.0 & 51.1 & 9.87 & 2.28 & 0.55 \\
\hline Textural Class & $\begin{array}{l}\text { Loam } \\
\text { y Sand }\end{array}$ & $\begin{array}{l}\text { Loamy } \\
\text { Sand }\end{array}$ & $\begin{array}{c}\text { Sandy } \\
\text { clay loam }\end{array}$ & Clay & $\begin{array}{c}\text { Sandy } \\
\text { loam }\end{array}$ & Sand & Sand \\
\hline $\begin{array}{l}\text { Bulk density } \\
\left(\mathrm{Mgm}^{-3}\right)\end{array}$ & 1.53 & 1.57 & 1.42 & 1.28 & 1.42 & 1.57 & 1.71 \\
\hline $\begin{array}{l}\text { Saturation } \\
\text { percent }(\%)\end{array}$ & 41.0 & 25.0 & 37.5 & 60.0 & 27.5 & 25.0 & 21.0 \\
\hline $\mathrm{pH}(1: 2.5)$ & 8.11 & 8.40 & 8.50 & 8.40 & 8.30 & 8.50 & 7.80 \\
\hline $\mathrm{EC}\left(\mathrm{dSm}^{-1}\right)$ & 2.90 & 2.40 & 2.80 & 2.46 & 2.61 & 0.70 & 1.82 \\
\hline $\begin{array}{l}\text { Soluble cations } \\
\left(\mathrm{meq}^{-1}\right)\end{array}$ & & & & & & & \\
\hline $\mathrm{Ca}^{2+}$ & 10.9 & 7.20 & 12.0 & 7.60 & 9.00 & 2.20 & 7.60 \\
\hline $\mathrm{Mg}^{2+}$ & 5.50 & 5.00 & 3.20 & 4.40 & 5.20 & 0.70 & 2.80 \\
\hline $\mathrm{Na}^{+}$ & 11.5 & 10.6 & 13.1 & 10.9 & 11.1 & 3.85 & 6.30 \\
\hline $\mathrm{K}^{+}$ & 1.13 & 1.20 & 1.30 & 1.60 & 1.70 & 1.25 & 1.10 \\
\hline $\begin{array}{l}\text { Soluble anions } \\
\left(\mathrm{meqI}^{-1}\right)\end{array}$ & & & & & & & \\
\hline $\mathrm{HCO}_{3}^{-}$ & 3.46 & 4.60 & 3.20 & 8.50 & 8.40 & 3.40 & 5.80 \\
\hline $\mathrm{CI}^{-}$ & 13.5 & 10.0 & 8.80 & 6.50 & 3.40 & 0.60 & 5.60 \\
\hline $\mathrm{SO}_{4}^{2-}$ & 12.0 & 10.2 & 16.0 & 9.60 & 9.20 & 3.00 & 6.80 \\
\hline Total $\mathrm{CaCO}_{3}, \%$ & 55.5 & 58.3 & 27.7 & 3.90 & 2.50 & 0.83 & 0.66 \\
\hline $\begin{array}{l}\mathrm{CEC},\left(\mathrm{CmoIKg}^{-1}\right. \\
\text { soil })\end{array}$ & 11.2 & 10.5 & 14.8 & 43.4 & 24.0 & 8.80 & 6.20 \\
\hline Organic matter (\%) & 0.22 & 0.36 & 0.74 & 1.59 & 0.54 & 0.29 & 0.07 \\
\hline $\begin{array}{l}\text { Available } \mathrm{P}, \mathrm{mg} \\
\mathrm{Kg}^{-1} \text { soil }\end{array}$ & 1.49 & 2.46 & 6.04 & 3.86 & 5.51 & 3.11 & 2.23 \\
\hline $\begin{array}{l}\text { Available } \mathrm{K}, \\
\mathrm{mgKg}^{-1} \text { soil }\end{array}$ & 6.90 & 7.16 & 10.9 & 13.0 & 12.4 & 9.30 & 5.90 \\
\hline
\end{tabular}

Soil reaction $(p H)$

\section{Results and Discussion}

Results in Table 2 show that the addition of elemental $\mathrm{S}$ to the soils caused a significant decrease in soil $\mathrm{pH}$. The decline in soil $\mathrm{pH}$ values increases with increasing elemental S application rates. The decrements in soil $\mathrm{pH}$ of Sudr, Wady El-Arish and Maryut after the addition of $2 \% \mathrm{~S}$ were $8.6,9$ and $10 \%$ for fine particles, 8,7 and $8 \%$ for coarse particles and 7, 5 and $8 \%$ for very coarse particles of S relative to the control $(0 \% \mathrm{~S})$, respectively. While in alluvial soils of Sakha and El-Mahsama, the decrement in soil $\mathrm{pH}$ values after the addition of $2 \%$ $\mathrm{S}$ were $9,11 \%$ for fine S particles, 4.5 and $10.5 \%$ for coarse S particles and 4 and $10 \%$ for very coarse S particles, respectively, relative to the control. In sandy soils of El-Manaief and Faculty Farm, the decrements in soil $\mathrm{pH}$ values after addition of $2 \% \mathrm{~S}$ were 25 and $16 \%$ for fine $\mathrm{S}$ particles, 23 and $14 \%$ for coarse $\mathrm{S}$ particles and 10.5 and $6 \%$ for very coarse $S$ particles, respectively, relative to the control. These decrements in soil $\mathrm{pH}$ values as a result of $\mathrm{S}$ application may be due to the oxidize of $\mathrm{S}$ to sulphuric acid by the soil microorganisms in amounts

Egypt. J. Soil Sci. 53, No. 3 (2013) 
enough to lower the soil $\mathrm{pH}$. These results were supported by Mary and Hao (1995) who stated that elemental S decreased soil $\mathrm{pH}$ through the production of sulfuric acid.

Similar conclusions were reported by Hammad et al. (2007) who found that elemental $\mathrm{S}$ is oxidized by microorganisms in soil to sulphuric acid which reduces soil $\mathrm{pH}$. Similar $\mathrm{pH}$ response to $\mathrm{S}$ application was previously reported by Dawood et al. (1985), Morsey (1985), Shadfan and Hussen (1985), Bole (1986), Hilal and Abdel-Fattah (1987), Modaihsh et al. (1989) and El Gamal et al. (1990).

TABLE 2. The effect of different rates and particle size of elemental sulphur application on soil $\mathrm{pH}$ of the incubated soil samples.

\begin{tabular}{|c|c|c|c|c|c|c|c|c|c|c|}
\hline \multirow[t]{2}{*}{ Location } & \multirow[t]{2}{*}{\begin{tabular}{|c|} 
Control \\
$\mathbf{S}_{\mathbf{0} \%}$ \\
\end{tabular}} & \multicolumn{3}{|c|}{ Fine $50 \mu$} & \multicolumn{3}{|c|}{ Coarse $250 \mu$} & \multicolumn{3}{|c|}{$\begin{array}{c}\text { Very coarse } \\
>250 \mu\end{array}$} \\
\hline & & $\mathbf{S}_{0.5 \%}$ & $\mathbf{S}_{\mathbf{1} \%}$ & $\mathbf{S}_{2} \%$ & $\begin{array}{c}\mathbf{S}_{0.5} \\
\%\end{array}$ & $\mathbf{S}_{1 \%}$ & $\mathbf{S}_{2} \%$ & \begin{tabular}{c|}
$\mathbf{S}_{0.5}$ \\
$\%$
\end{tabular} & $\mathbf{S}_{1 \%}$ & $\mathbf{S}_{\mathbf{2}} \%$ \\
\hline Ras Sudr & 8.66 & 8.00 & 7.98 & 7.91 & 8.10 & 8.07 & 7.95 & 8.10 & 8.10 & 8.07 \\
\hline Wady El-Arish & 8.50 & 7.90 & 7.78 & 7.70 & 7.92 & 7.75 & 7.91 & 8.33 & 8.12 & 8.09 \\
\hline Maryut & 8.75 & 8.07 & 8.06 & 7.91 & 8.10 & 8.00 & 8.05 & 8.29 & 8.17 & 8.08 \\
\hline Sakha & 8.37 & 7.90 & 7.73 & 7.60 & 8.12 & 8.07 & 7.99 & 8.09 & 8.01 & 8.00 \\
\hline El-Mahsama & 7.97 & 7.45 & 7.12 & 7.09 & 7.39 & 7.14 & 7.13 & 7.3 & 7.29 & 7.15 \\
\hline El- Manaief & 8.28 & 7.90 & 6.42 & 6.23 & 7.57 & 6.62 & 6.37 & 7.95 & 7.76 & 7.41 \\
\hline Faculty Farm & 7.93 & 6.97 & 6.83 & 6.67 & 7.17 & 7.09 & 6.80 & 7.64 & 7.46 & 7.43 \\
\hline
\end{tabular}

LSD (location) $0.05=0.114, \mathrm{LSD}$ (size S) $0.05=0.074, \mathrm{LSD}$ (levels S) $0.05=0.086$.

Results in Table 2 also revealed that the decrease in soil $\mathrm{pH}$ values were high in the investigated amended with the fine particle size of S compared with its coarse and very coarse size .In this respect, Janzen and Bettany (1987 a) illustrated that $\mathrm{S}$ oxidation is depended on the particle surface area than its mass, because the oxidation is a surface reaction and only $\mathrm{S}$ atoms at the exterior surface are oxidized. Thus, more $\mathrm{SO}_{4}{ }^{2-}$ is produced from reduced $\mathrm{S}$ compounds (including elemental $\mathrm{S}$ ) with larger surface areas than that from compounds with smaller surface areas. Similar conclusions were reported by Reda and Modaihsh (1990), who found that the fineness of S particles and the efficiency of mixing $\mathrm{S}$ with soil play a major role in $\mathrm{S}$ oxidation in addition to the related chemical changes in soil. The examination of soil thin sections revealed that $\mathrm{S}$ particles $<100$ micron were almost completely oxidized where large granules were only slightly affected. Lee et al. (1990) also found that more bacteria of thiobacillis were found in soils treated with finely divided elemental $\mathrm{S}$ than with more coarse particles. The results in Table 2 also show that the decrements in soil $\mathrm{pH}$ value of sandy soils were more than in the other investigated soils. This may be due to that the sandy soils always contain more air and oxygen accelerating the oxidation of $\mathrm{S}$ by aerobic microorganisms to sulphate. In this respect, Janzen and Bettany (1987b) reported that different textured soils have different oxidation rates. For example, clay soils contain more moisture and less air-filled porosity at field capacity than coarser-textured soils. In turn, oxidation rates at field capacity in clay soils are lower due to the Egypt. J. Soil Sci. 53, No. 3 (2013) 
oxygen diffusion into soil pores may be lower in heavier textured soils. Textural effects may be most important only at or near soil field capacity. Similar conclusions were reported by Zhao et al. (1996 a ) who found that the percentage of total oxidized $\mathrm{S}$ appearing as sulphate $-\mathrm{S}$ were greater in two sandy soils than in two clay soils after 38 days of incubation at $25^{\circ} \mathrm{C}$. The difference between the oxidation rates of $S$ and the production of sulphate-S was probably due to microbial immobilization. Also, Zhihui et al. (2008) found that soil $\mathrm{pH}$ decreased rapidly from an initial value of 7.6 to 5.3 after 15 days of the first $S$ application in an incubation experiment.

\section{Electrical conductivity (EC)}

The results in Table 3 show clearly that $\mathrm{S}$ applications led to significant increase the electrical conductivity of 1:2.5 soil water extract of the soils at the end of the incubation period. Generally, increasing $S$ application led to a significant increase in the EC values in all investigated soils. In regard to the effect of different size fractions, the results in Table 3 show that by using $2 \%$ of fine $\mathrm{S}$ particles increases of EC in calcareous soils of Ras Sudr, Wady El-Arish and Maryut by 89, 169.6 and $94 \%$, respectively. These increments reached to $85,154,84 \%$ for coarse and very coarse $\mathrm{S}$ particles. These increments were $78,150.6,49 \%$, respectively relative to the control. It is noteworthy that the soil which has high initial salinity such as Ras sudr soil shows a minimum change in salt concentration.

TABLE 3. The effect of different rates and particle size of elemental sulphur application on electrical conductivity of the incubated soil samples $\left(\mathrm{dSm}^{-1}\right.$ in $1: 2.5$ soil extract $)$.

\begin{tabular}{|c|c|c|c|c|c|c|c|c|c|c|}
\hline \multirow[t]{2}{*}{ Location } & \multirow[t]{2}{*}{\begin{tabular}{|c} 
Control \\
$\mathbf{S}_{\mathbf{0} \%}$ \\
\end{tabular}} & \multicolumn{3}{|c|}{ Fine $50 \mu$} & \multicolumn{3}{|c|}{ Coarse $250 \mu$} & \multicolumn{3}{|c|}{ Very coarse $>250 \mu$} \\
\hline & & $\mathbf{S}_{0.5 \%}$ & $\mathbf{S}_{1 \%}$ & $\mathbf{S}_{2 \%}$ & $\mathbf{S}_{0.5 \%}$ & $\mathbf{S}_{1 \%}$ & $\mathbf{S}_{2 \%}$ & $\mathbf{S}_{0.5 \%}$ & $\mathbf{S}_{1 \%}$ & $\mathbf{S}_{2 \%}$ \\
\hline Ras Sudr & 1.48 & 2.10 & 2.45 & 2.80 & 2.61 & 2.73 & 2.74 & 2.35 & 2.48 & 2.64 \\
\hline Wady El-Arish & 0.79 & 2.04 & 2.07 & 2.13 & 1.65 & 1.80 & 2.01 & 0.91 & 1.44 & 1.98 \\
\hline Maryut & 1.34 & 2.00 & 2.09 & 2.60 & 1.86 & 2.07 & 2.47 & 1.75 & 1.82 & 2.00 \\
\hline Sakha & 1.09 & 2.15 & 2.17 & 2.37 & 1.62 & 2.15 & 2.17 & 1.45 & 1.67 & 1.83 \\
\hline El-Mahsama & 0.92 & 1.52 & 1.63 & 1.90 & 1.47 & 1.80 & 1.85 & 1.37 & 1.38 & 1.80 \\
\hline El- Manaief & 0.55 & 1.20 & 1.51 & 1.52 & 1.05 & 1.28 & 1.32 & 0.76 & 1.27 & 1.03 \\
\hline Faculty Farm & 0.38 & 0.88 & 0.94 & 1.13 & 0.70 & 0.86 & 0.94 & 0.70 & 0.76 & 0.79 \\
\hline
\end{tabular}

These results may be due to the low activity of microorganisms caused by the high salt concentration, followed by a low rate of $S$ oxidation in highly saline soils. This should be considered when $\mathrm{S}$ is applied to highly saline and alkaline soils. Similar conclusion were reported by Khater (1981), Yousry et al. (1984 a) and Shadfan \& Hussen (1985). In the alluvial soils of Sakha and El-Mahsama, the increments after applying $2 \% \mathrm{~S}$ were 117.4 and $106.5 \%$ for fine S particles, while they were 99 and $101 \%$ for coarse S particles and were 74 and $95.6 \%$ for very coarse $S$ particles, respectively, relative to the control treatment. However, the sandy soils of El-Manaief and Faculty Farm soils were 176 and $197 \%$ for 
the fine S particles; 140 and $147 \%$ for the coarse S particles and 87 and $108 \%$ for the very coarse $\mathrm{S}$ particles, respectively. The highest $\mathrm{EC}$ values of alluvial soils resulted from the addition of $\mathrm{S}$ would decrease soil $\mathrm{pH}$ values through oxidation of $\mathrm{S}$ by soil microorganisms and producing sulphuric acid in amounts enough to lower $\mathrm{pH}$ and consequently increased the solubility of different salts. In this respect, Abdel-Fattah et al. (1984) reported that the EC values of soil extract were increased with increasing both level of $\mathrm{S}$ application and the incubation period. Similar conclusions were reported by Ali et al. (1991b), Mary and Hao (1995), Atia (2005) and Velarde et al. (2005). It is worthy to note that EC at low level of soil moisture content was greater than that at the high moisture level. These results are in agreement with those obtained by Burns (1984) who reported that the moisture content for maximal S oxidation in soil was below the field capacity. In this respect, Abdel-Fattah and Hilal (1985) reported that the magnitude of the variation in the EC is depended on the level of $\mathrm{S}$ application and soil type.

\section{Soluble sulphate}

The concentration of soluble sulphate in 1:2.5 soil water extract from different particle size and rates of elemental $\mathrm{S}$ application at the end of incubation period were shown in Table 4. The results show that the $\mathrm{S}$ application rates increase the soluble sulfate significantly. With the exception for Maryut soil, the calcareous soils give the highest values of soluble sulfate, while, sandy soils recorded the lowest values. These results may be due to that calcareous were saline soils. The obtained results show also that soluble sulphate is significantly increased with the finest $\mathrm{S}$ particles at different rates in the investigated soils. The increments in soluble sulphate result from the addition of fine, coarse and very coarse particle size of S, $<2 \%$ of S, were 81 , 61 and $52 \%$ for Ras Sudr, respectively, relative to the control treatment. The soluble S values for Wady El- Arish were 214, 189 and $134 \%$ and for Maryut soil sample were 282,232 and $214 \%$, respectively relative to control. Respecting to the alluvial soils, their figures were 347,213 and $270 \%$ for Sakah, and 206, 133 , and $198 \%$ for El-Mahsama soils, respectively relative to the control. However, sandy soils of El- Manaief and Faculty Farm have the lowest increments in soluble sulphate by $185,63 \%, 118,41 \%$ and $108,31 \%$ relative to the control (0S) for fine, coarse and very coarse $\mathrm{S}$ particles, respectively. The results also show that the amount of soluble sulphate in all the investigated soils increases with increasing elemental S level as compared with the control treatment.

Regarding to the effect of $\mathrm{S}$ treatments on the soluble sulphate, the results in the Table 4 show that the highest value of sulphate was at $2 \% \mathrm{~S}$ as compared with the other levels of elemental S. This may be due to the highest reduction in soil $\mathrm{pH}$, and the transformation of $\mathrm{S}$ to sulphuric acid by soil microorganisms. In this respect, Nasseem and Nasrallah (1981) showed that the applied $S$ is slowly oxidized at a low rate and it may be affected by the activity of sulphur oxidation microorganisms in soil. Generally, it could be concluded that the highest amount of sulphate was found with fine particle size of elemental $\mathrm{S}$

Egypt. J. Soil Sci. 53, No. 3 (2013) 
treatment in all soils under consideration. Similar results were found by Admaczyk Winiarska et al. (1975) who showed that the soil riches in S and calcium carbonate can produce more sulphate than soil having meager in calcium carbonate and treated with S. Similar results are found by Itanna (2005) who reported that the silt and clay - rich horizons in the solonetz particularly have sulfate enrichment, possibly because differences in particle size influence sulfate adsorption and clay fractions were found to have higher $\mathrm{S}$ concentration compared to coarse textured soil. These findings conferment those obtained results from Sakha soil which have the highest amounts of clay and ElMahsama soil which it was sandy loam in texture. Similar conclusion was reported by CaldWell (1967) who stated that, generally, the amount of S oxidize to soluble sulphate in sandy loam soil increases with particle sizes $<100$ mesh.

TABLE 4. The effect of different rates and particle size of elemental sulphur application on soluble sulphate after incubation period of soil samples $\mathrm{mg} \mathrm{SO}_{4}{ }^{2-} / 100 \mathrm{~g}$ soil.

\begin{tabular}{|c|c|c|c|c|c|c|c|c|c|c|}
\hline \multirow{2}{*}{ Location } & \multirow{2}{*}{$\begin{array}{c}\text { Control } \\
S_{0} \%\end{array}$} & \multicolumn{3}{|c|}{ Fine $50 \mu$} & \multicolumn{3}{|c|}{ Coarse $250 \mu$} & \multicolumn{3}{|c|}{ Very coarse $>250 \mu$} \\
\hline & & $S_{05 \%}$ & $\mathbf{S}_{1 \%}$ & $\mathbf{S}_{2 \%}$ & $S_{05 \%}$ & $\mathbf{S}_{1 \%}$ & $\mathbf{S}_{2 \%}$ & $\mathrm{~S}_{05} \%$ & $\mathbf{S}_{1 \%}$ & $\mathbf{S}_{2 \%}$ \\
\hline Ras Sudr & 251 & 312 & 373 & 454 & 287 & 407 & 404 & 329 & 350 & 380 \\
\hline $\begin{array}{l}\text { Wady El- } \\
\text { Arish }\end{array}$ & 170 & 425 & 566 & 580 & 232 & 382 & 490 & 221 & 287 & 397 \\
\hline Maryut & 67.4 & 185 & 223 & 257 & 160 & 230 & 223 & 151 & 151 & 212 \\
\hline Sakha & 155 & 227 & 552 & 694 & 255 & 528 & 574 & 158 & 211 & 362 \\
\hline El-Mahsama & 45.7 & 111 & 130 & 143 & 113 & 124 & 140 & 120 & 120 & 136 \\
\hline El- Manaief & 41.2 & 105 & 107 & 118 & 73.0 & 89.9 & 89.9 & 49.7 & 64.2 & 85.7 \\
\hline $\begin{array}{l}\text { Faculty } \\
\text { Farm }\end{array}$ & 87.9 & 103 & 107 & 143 & 87.9 & 98.5 & 124 & 96.3 & 113 & 115 \\
\hline
\end{tabular}

LSD (location) $0.05=41.3$, LSD (sizes S) $0.05=27.0$, LSD (levels S) $0.05=31.2$.

\section{Extractable phosphorus}

Results in Table 5 summarize the effect of different particle sizes and rates of elemental $\mathrm{S}$ application on the availability of phosphorus in the investigated soils at the end of the incubation period. The amounts of $\mathrm{NaHCO}_{3}{ }^{-3}$ extractable phosphorus significantly and progressively increase with increasing elemental $\mathrm{S}$ applications from 0 up to $2 \%$ under the different particle size of $\mathrm{S}$ treatments. This may be due to the decrease in soil $\mathrm{pH}$ as mentioned above which led to increase the $\mathrm{S}$ oxidation and the production of sulphuric acid by soil microorganisms and consequently increases the available P. Regardless the effect of particle size of elemental S, increasing S application in the incubation experiment from $0.5 \%$ up to $2 \%$ increases the extractable P from different soils. These increments from calcareous soils, Ras Sudr, Wady El-Arish and Maryut soils were $145 \%, 143 \%$ and $121 \%$, respectively, relative to the control treatment. While, Sakah and El-Mahsama soils record 121 and $126 \%$, respectively, relative to the control treatment. The percentages of increase extractable $\mathrm{P}$ under application $2 \% \mathrm{~S}$ for its fine, coarse and very coarse particle size in calcareous soils of Ras sudr reach to $103,58.5$ and $45 \%$, while they were $81.5,49$ and $34 \%$ for Wady El-Arish and were 42,18 and $27 \%$ for Maryut, 
respectively, relative to the control. These figures for alluvial soils were 41, 52 and $27 \%$ for Sakha and 28, 16 and $24 \%$ for El-Mahsama, respectively, for fine, coarse and very coarse particle size of $\mathrm{S}$ relative to the control. While the increments in the extractable of Phosphorus in sandy soils of were 29, 69 and 17 $\%$ in El-Manaief soil, while the values were 60.5, 8 and $37.6 \%$ in Faculty Farm soil, respectively, for fine, coarse and very coarse particle size of S relative to the control treatment. It is interest to note that the highest extractable $\mathrm{P}$ in calcareous soils was obtained from the saline soil of Ras Sudr while the lowest figure was recorded in Maryut soil which has the lowest amount of salt content.

Similar results were obtained by Anter and Hilal (1981), Shadfan and Hussen (1985) and Jalilehvand (2006) who found that the availability of phosphate was higher in calcareous saline soil than the other calcareous soils. These results also revealed that the chemically available $\mathrm{P}$ was clearly increased by increasing elemental $S$ application rates under the three particle sizes of $S$ and this may be due to the decrease in soil $\mathrm{pH}$ as aforementioned due to $\mathrm{S}$ oxidation and the production of sulphuric acid by soil microorganisms.

The results in Table 5 also show that the increase of S application from $0.5 \%$ to $2 \%$ progressively increases the extractable $-\mathrm{P}$ for all soil samples at the end of incubation period. These results stand in a good agreement with that obtained by Ali et al. ( $1991 \mathrm{~b}$ ) who found that the amount of P extracted increased progressively by increasing the application rates of $\mathrm{S}$. They added that the increased $\mathrm{S}$ rates resulted in increased levels of soluble $\mathrm{SO}_{4}^{2-}$, followed by lower soil $\mathrm{pH}$. This, in turn, would increase the extractability of $\mathrm{P}$ and its availability to plants. Similar finding was reported by Abdel-Fattah et al. (2005) who found that the availability of $\mathrm{P}$ increased with increasing $\mathrm{S}$ application rates. The magnitude of increasing $\mathrm{P}$ availability is depended on soil type at the following order: calcareous soil > sandy soil > clay loam soil. It was concluded that application of 1 or 2 tons S per acre resulted in supplying a suitable amounts of available phosphorus.

TABLE 5. Effect of different rates and particle size of elemental sulphur application on the $\mathrm{NaHCO}_{3}$ extractable phosphate from the incubated soil samples $\left(\mu \mathrm{gg}^{-1}\right)$.

\begin{tabular}{|c|c|c|c|c|c|c|c|c|c|c|}
\hline \multirow{2}{*}{ Location } & \multirow{2}{*}{$\begin{array}{c}\text { Control } \\
\mathrm{S}_{0 \%}\end{array}$} & \multicolumn{3}{|c|}{ Fine $50 \mu$} & \multicolumn{3}{|c|}{ Coarse $250 \mu$} & \multicolumn{3}{|c|}{ Very coarse $>250 \mu$} \\
\hline & & $S_{0.5 \%}$ & $\mathbf{S}_{1 \%}$ & $\mathbf{S}_{2} \%$ & $S_{0.5 \%}$ & $\mathbf{S}_{1 \%}$ & $\mathbf{S}_{2} \%$ & $S_{0.5 \%}$ & $\mathbf{S}_{1 \%}$ & $\mathbf{S}_{2 \%}$ \\
\hline Ras Sudr & 1.46 & 1.59 & 2.05 & 2.96 & 1.83 & 2.46 & 2.65 & 1.51 & 1.90 & 2.07 \\
\hline $\begin{array}{l}\text { Wady El- } \\
\text { Arish }\end{array}$ & 46 & 3.15 & 3.61 & 3.90 & 3.00 & 3.42 & 3.67 & 0 & 2.60 & 2. \\
\hline Maryut & 5.70 & 5.81 & 6.77 & 8.25 & 6.07 & 6.95 & 7.64 & 6.39 & 6.99 & 7.24 \\
\hline Sakha & 3.53 & 3.92 & 4.03 & 4.99 & 4.11 & 4.76 & 4.50 & 3.90 & 4.05 & 4.10 \\
\hline El- Mahsama & 5.51 & 7.04 & 8.19 & 8.40 & 5.65 & 6.62 & 7.06 & 6.42 & 6.47 & 6.84 \\
\hline El- Manaief & 3.78 & 3.96 & 4.62 & 4.88 & 3.86 & 4.27 & 4.43 & 3.83 & 3.90 & 4.08 \\
\hline Faculty Farm & 2.23 & 2.63 & 3.73 & 3.77 & 2.29 & 2.34 & 3.58 & 2.13 & 2.44 & 3.07 \\
\hline
\end{tabular}

LSD (location) $0.05=0.220$, LSD (sizes S) $0.05=0.144$, LSD (levels S) $0.05=0.166$.

\section{Extractable potassium}

Egypt. J. Soil Sci. 53, No. 3 (2013) 
The results clearly show that available $-\mathrm{K}$ extracted from investigated soils treated with different particle size of $\mathrm{S}$ under different $\mathrm{S}$ application rates are progressively and significantly increased. The increments in the amounts of available $-\mathrm{K}$ at the rate of $2 \% \mathrm{~S}$ for the calcareous soils of Ras Surd were 17, 13 and $5 \%$ for fine, coarse and very coarse S particles, respectively, relative to the control treatment .These figures for Wady El-Arish soil were 12, 9 and $7, \%$ while they were 7, 1 and $0.6, \%$ for Maryut soil respectively. The highest increment from available $-\mathrm{K}$ under different particle size of elemental $\mathrm{S}$ was obtained from Ras Sudr loamy sand soil which contains not \% $82.62>$ sand. This result was expected because it is known that the calcareous sandy soil ordinary contains relatively high content of K-bearing minerals in the primary form such as mica, orthoclase, etc .Consequently, these primary minerals are easily broken down by sulphuric acid which resulted from $\mathrm{S}$ oxidation by soil microorganisms. In this respect, Ali (1974) studied the K supplying power of calcareous soils and found that high amounts of $\mathrm{K}$ were obtained from the sandy calcareous soils.

Regarding to the alluvial soils the results in Table 6 show that with increasing rates of elemental S up to $2 \%$ increased the available K in Sakha soil by 34,25 and $6 \%$ for fine, coarse and very coarse S particles, respectively, relative to the control treatment. These figures for El-Mahsama soil were 16, 5 and $2 \%$, respectively. While the increments in the available $\mathrm{K}$ in sandy soils of El-Manaief were 26, 16 and $11 \%$ for fine, coarse and very coarse particle size of $\mathrm{S}$, respectively, relative to the control treatment. The corresponding figures for the Faculty Farm were 28, 24 and $8 \%$ respectively. Generally, the amount of increase in the available $\mathrm{K}$ in the different soils under consideration varied between 100 and $106 \%$ relative to the control treatment, indicating that the elemental S application play a useful role in the available $\mathrm{K}$ in the investigated soils, especially by using fine S particles. In this respect, Ali et al. (1991b) reported that the application of elemental $\mathrm{S}$ for calcareous soils increased the availability of $\mathrm{P}$ and $\mathrm{K}$ in these soils.

Similar conclusion reported by Yousry et al. (1984b), Ismail (1997), ElSersawy et al.(1992), Beheiry (1993), Beheiry et al.(1997) and Eriksen (2009) stated that $\mathrm{S}$ application significantly increased exchangeable $\mathrm{K}$ in calcareous soil. They added that such effects may be due to the effect of transformation of $\mathrm{S}$ to sulphuric acid and its substantial effect on dissolution of primary $\mathrm{K}$ bearing minerals. Additional conclusion were reported by El-Ghanam et al. (1999) who found that $\mathrm{S}$ application rates had significant effect on available $\mathrm{K}$ and $\mathrm{P}$ in the amended soils. 
TABLE 6. Effect of different rates and particle size of elemental sulphur application on the extracted potassium after the incubation period of soil samples (mg/100g soil).

\begin{tabular}{|c|c|c|c|c|c|c|c|c|c|c|}
\hline \multirow{2}{*}{ Location } & \multirow{2}{*}{$\begin{array}{c}\text { Control } \\
\mathrm{S}_{\mathbf{0}} \%\end{array}$} & \multicolumn{3}{|c|}{ Fine $50 \mu$} & \multicolumn{3}{|c|}{ Coarse $250 \mu$} & \multicolumn{3}{|c|}{ Very coarse $>250 \mu$} \\
\hline & & $\mathbf{S}_{0.5 \%}$ & $\mathbf{S}_{1 \%}$ & $\mathbf{S}_{2} \%$ & $\mathbf{S}_{0.5 \%}$ & $\mathbf{S}_{1 \%}$ & $\mathbf{S}_{2} \%$ & $\mathbf{S}_{0.5} \%$ & $\mathbf{S}_{1 \%}$ & $\mathbf{S}_{2} \%$ \\
\hline Ras Sudr & 13.2 & 14.5 & 14.9 & 15.5 & 13.8 & 14.0 & 15.0 & 13.3 & 13.50 & 13.9 \\
\hline $\begin{array}{l}\text { Wady El- } \\
\text { Arish }\end{array}$ & 12.5 & 13.0 & 13.6 & 14.0 & 12.5 & 13.0 & 13.6 & 12.7 & 13.0 & 1. \\
\hline Maryut & 40.5 & 41.0 & 41.0 & 43.5 & 40.5 & 40.9 & 41.0 & 40.5 & 40.7 & 40.8 \\
\hline Sakha & 35.3 & 38.0 & 38.5 & 47.5 & 41.6 & 43.5 & 44.0 & 36.0 & 36.5 & 37.5 \\
\hline El- Mahsama & 16.8 & 17.5 & 19.0 & 19.5 & 17.0 & 17.5 & 17.7 & 17.0 & 17.2 & 17.3 \\
\hline El- Manaief & 9.50 & 9.50 & 10.0 & 12.0 & 10.0 & 10.0 & 11.0 & 10.0 & 10.5 & 09.5 \\
\hline Faculty Farm & 13.3 & 15.5 & 16.5 & 17.0 & 14.5 & 15.0 & 16.5 & 13.5 & 14.0 & 14.3 \\
\hline
\end{tabular}

LSD (location) $0.05=1.05$, LSD (sizes S) $0.05=0.688$, LSD (levels S) $0.05=0.795$.

\section{DTPA- extractable Fe}

The obtained results show that the extractable Fe significantly increased with increasing level of elemental S up to $2 \%$.These increments for Ras Sudr, Wady El-Arish and Maryut calcareous soil samples were 134, 224 and $229 \%$, respectively, relative to the control treatment. These figures for El- Mahsama, El-Manaief and Faculty Farm were 128, 298 and $208 \%$, respectively. While the alluvial soil sample of Sakha recorded the lowest percentage of increment (i.e., $166 \%)$. Respecting the increments results from different particle size of elemental $\mathrm{S}$, the results show that the percentages of increase at the rate of $2 \%$ relative to the control in the calcareous soils of Ras Sudr reach to 70, 61 and $14 \%$ for fine, coarse and very coarse, respectively. These figures for Wady El-Arish were 286, 181 and $124 \%$, respectively, and for Maryut soil samples were 230, 209 and 89 \%, respectively. The results clearly show that the finest particle size of $\mathrm{S}$ led to significantly increase in the extractable $\mathrm{Fe}$ in all soils under consideration. Also, this finding may be due to the decrease of soil $\mathrm{pH}$ as a result of $\mathrm{S}$ oxidation to sulphuric acid, especially under the fine particle size of $S$ and consequently increased the extractable Fe. Such results are in harmony with those reported by Ryan et al. (1974), Khater (1981), Yousry et al. (1984b) and Mostafa et al. (1990) who found that $\mathrm{S}$ application increased Fe extracted by DTPA in calcareous soils.

In this respect, Kalbasi et al. (1988) found that the application of elemental S to the calcareous soils decreased $\mathrm{pH}$ and $\mathrm{HCO}_{3}{ }^{-}$concentration and increased available $\mathrm{Fe}$ in soil. They added that the available Fe increased in S-amended calcareous soils only at the highest rate of application up to $3 \%$ after 18 weeks of incubation where the soil $\mathrm{pH}$ was lowest. Regarding to the values resulted from Sakha and El-Mahsama soils, the results show that extractable Fe progressively increased with increasing the rate of S application. These increments up to $2 \% \mathrm{~S}$ application were $166 \%$ for Sakha and $128 \%$ for El-Mahsama soil relative to the control treatment. With regard to the effect of the particle size of $S$, the results show that the increments relative to the control treatment were 214, 144 and $92 \%$ for fine, coarse and very coarse of S particle size for Sakha soil and $72 \%, 39 \%$ and $26 \%$ for El-Mahsama soil, respectively. The increments in

Egypt. J. Soil Sci. 53, No. 3 (2013) 
extractable $\mathrm{Fe}$ of El-Manaief and Faculty Farm sandy soils relative to the control resulted from increasing rate of S application up to $2 \%$ were 298 and $208 \%$, respectively. While these increments resulted from different particles of $\mathrm{S}$ application under $2 \% \mathrm{~S}$ were 378, 296 and $224 \%$ for fine, coarse and very coarse S particles for El-Manaief soil, respectively. These figures for Faculty Farm soil were 262, 146 and $108 \%$, respectively. In this respect, Khater (1981) found that the application of $\mathrm{S}$, generally, increased available $\mathrm{P}$ in alluvial soil as well as available Fe and $\mathrm{Zn}$. Similar conclusion were reported by Mostafa et al. (1990) who stated that soluble Fe and Mn were clearly increased in different soil layers as a result of $\mathrm{S}$ incorporation into the soil. Also, Abd ElFattah and Hilal (1984) found that the available $\mathrm{Fe}, \mathrm{Mn}, \mathrm{Zn}$ and $\mathrm{Cu}$ increased as a result of $\mathrm{S}$ application to the sandy, calcareous and clay loam soils as compared with those in control soil without $\mathrm{S}$ treatment (Table 7).

TABLE 7. Effect of different rates and particle size of elemental sulphur application on the extracted iron after incubation period ( $\mu g g-1)$.

\begin{tabular}{|c|c|c|c|c|c|c|c|c|c|c|}
\hline \multirow[t]{2}{*}{ Location } & \multirow[b]{2}{*}{$\begin{array}{c}\text { Control } \\
\mathbf{S}_{0 \%}\end{array}$} & \multicolumn{3}{|c|}{ Fine $50 \mu$} & \multicolumn{3}{|c|}{ Coarse $250 \mu$} & \multicolumn{3}{|c|}{ Very coarse $>250 \mu$} \\
\hline & & $\mathbf{S}_{0.5 \%}$ & $\mathbf{S}_{\mathbf{1} \%}$ & $\mathbf{S}_{\mathbf{2} \%}$ & $\mathbf{S}_{0.5 \%}$ & $\mathbf{S}_{\mathbf{1} \%}$ & $\mathbf{S}_{\mathbf{2}} \%$ & $\mathbf{S}_{0.5 \%}$ & $\mathbf{S}_{1 \%}$ & $\mathbf{S}_{\mathbf{2} \%}$ \\
\hline Ras Sudr & 3.68 & 4.48 & 5.96 & 6.24 & 4.02 & 5.88 & 5.92 & 3.78 & 3.92 & 4.18 \\
\hline Wady ELArish & 1.40 & 2.64 & 2.82 & 5.40 & 2.38 & 3.18 & 3.94 & 2.42 & 2.92 & 3.13 \\
\hline Maryut & 4.64 & 9.52 & 13.8 & 15.30 & 9.38 & 11.2 & 14.3 & 6.58 & 7.20 & 8.78 \\
\hline Sakha & 5.80 & 6.44 & 9.02 & 18.2 & 6.12 & 8.28 & 14.2 & 6.14 & 7.16 & 11.2 \\
\hline El-Mahsama & 2.39 & 2.72 & 3.16 & 4.10 & 2.66 & 2.70 & 3.32 & 2.94 & 2.99 & 3.00 \\
\hline El-Manaief & 1.60 & 4.00 & 5.16 & 7.64 & 3.66 & 4.84 & 6.34 & 2.16 & 3.90 & 5.18 \\
\hline Faculty Farm & 1.05 & 1.78 & 2.26 & 3.80 & 1.58 & 2.34 & 2.58 & 1.26 & 1.86 & 2.18 \\
\hline
\end{tabular}

\section{DTPA-extractable $\mathrm{Mn}$}

Results in Table 8 show the effect of the rates of elemental S application and its particle size on the DTPA-extractable Mn in the studied soils .The obtained results indicated that the extracted $\mathrm{Mn}$ increased with increasing elemental $\mathrm{S}$ application rates up to $2 \%$. The percentages increase in the calcareous soils of Ras Sudr, Wady El-Arish and Maryut soils, irrespective to the particle size of elemental- S were 168, 122 and $118 \%$, respectively, relative to the control treatment. These increments for alluvial soils, Sakha and El-Mahsama soils were 116 and $129 \%$, respectively. While extracted $\mathrm{Mn}$ from sandy soils of El-Manaief and Faculty Farm were 129 and $228 \%$, respectively, relative to the control treatment.

In this respect, Abdel- Fattah and Hilal (1984), Kalbasi et al. (1988) and Modaihsh et al. (1989) reported that all rates of $\mathrm{S}$ application significantly increased available $\mathrm{Mn}$ in calcareous soils. The highest values of available $\mathrm{Mn}$ were produced in the surface soil $(0-10 \mathrm{~cm})$ after 3-6 weeks of incubation and they were not associated with the lower $\mathrm{pH}$ values. Similar finding was reported by Khater (1981) and Yousry et al. (1984b) who reported that the increase in available $\mathrm{Mn}$ in soil accompanying the oxidation of $\mathrm{S}$ is due to the reducing effect of S and not dissolving of acidity. El-Fayoumy and El-Gamal (1998) observed that $\mathrm{S}$ application significantly increased DTPA extractable Mn in surface and 
sub- surface soil layers. Regarding to the effect of particle size of elemental S on the extractable $\mathrm{Mn}$ in different soils under consideration, results in Table 8 show that extractable Mn significantly increase with the finest of elemental $\mathrm{S}$ under different rates of $\mathrm{S}$.

TABLE 8. Effect of different rates and particle size of elemental sulphur application on the extracted manganese after incubation period ( $\mu \mathrm{gg}-1)$.

\begin{tabular}{|c|c|c|c|c|c|c|c|c|c|c|}
\hline \multirow[t]{2}{*}{ Location } & \multirow{2}{*}{\begin{tabular}{|c|} 
Control \\
$\mathbf{S}_{0 \%}$
\end{tabular}} & \multicolumn{3}{|c|}{ Fine $50 \mu$} & \multicolumn{3}{|c|}{ Coarse $250 \mu$} & \multicolumn{3}{|c|}{ Very coarse $>250 \mu$} \\
\hline & & $\mathbf{S}_{0.5 \%}$ & $\mathbf{S}_{1 \%}$ & $\mathbf{S}_{\mathbf{2} \%}$ & $\mathbf{S}_{0.5 \%}$ & $\mathbf{S}_{1 \%}$ & $\mathbf{S}_{2} \%$ & $\mathbf{S}_{0.5 \%}$ & $\mathbf{S}_{1 \%}$ & $\mathbf{S}_{2} \%$ \\
\hline Ras Sudr & 5.30 & 7.40 & 9.64 & 12.3 & 7.00 & 9.16 & 10.8 & 6.88 & 7.22 & 9.76 \\
\hline Wady El-Arish & 6.58 & 7.18 & 8.46 & 10.3 & 6.62 & 7.48 & 9.76 & 6.16 & 7.38 & 8.70 \\
\hline Maryut & 8.77 & 9.00 & 10.6 & 14.3 & 8.92 & 9.70 & 11.5 & 8.94 & 9.98 & 10.5 \\
\hline Sakha & 9.91 & 10.3 & 12.6 & 15.5 & 10.3 & 11.2 & 12.5 & 9.80 & 10.4 & 11.3 \\
\hline El- Mahsama & 8.34 & 9.98 & 11.1 & 13.9 & 9.06 & 11.2 & 12.6 & 9.00 & 9.60 & 10.1 \\
\hline El- Manaief & 6.59 & 7.12 & 8.28 & 11.3 & 6.68 & 8.20 & 10.2 & 6.84 & 8.74 & 9.42 \\
\hline Faculty Farm & 1.66 & 2.48 & 4.88 & 6.40 & 2.20 & 3.76 & 4.56 & 2.78 & 3.06 & 4.04 \\
\hline
\end{tabular}

LSD (location) $0.05=0.164$, LSD (sizes S) $0.05=0.052$, LSD (levels S) $0.05=0.075$.

The increment of extractable Mn under the rate of $2 \% \mathrm{~S}$ application to Ras Sudr soil was 131, 103 and $84 \%$ relative to the control treatment for fine, coarse and very coarse $\mathrm{S}$ particle size, respectively. These figures for Wady El-Arish were 56, 48 and $32 \%$ and were 63, 31 and $20 \%$ in Maryut soil, respectively. The increments in extractable $\mathrm{Mn}$ of Sakha soil relative to the control treatment were 56, 26 and $14 \%$ and were 67, 51 and $22 \%$ in El-Mahsama soil, for fine, coarse and very coarse elemental S, respectively. While in sandy soils of El-Manaief, these increments in extractable Mn were 71, 55 and $43 \%$ and they were 286, 175 and $143 \%$ in Faculty Farm soil, for fine, coarse and very coarse elemental $\mathrm{S}$, respectively, relative to the control treatment. In this respect, Diab et al. (1995) concluded that $\mathrm{S}$ treatments were more effective in increasing the availability of micronutrients in soil, followed by gypsum application. This was true for both saline alkali and alkali soils. The application of $\mathrm{S}$ to calcareous and alkaline soils was aimed to increase the micronutrients solubility by lowering soil pH. Similar conclusion was reported by Youssef (1997) who used rhizobox technique to study the movement of $\mathrm{Mn}$ in relation to $\mathrm{S}$ application in the rhizosphere of wheat seedlings. He found that $\mathrm{S}$ application increased significantly the extractable $\mathrm{Mn}$ across the rhizosphere, where the content of $\mathrm{Mn}$ was always highest in the central compartment.

\section{Conclusions}

The application of elemental $\mathrm{S}$ at rates up to $2 \%$ to seven soils in an incubation experiment reduced $\mathrm{pH}$ values relative to the control treatment. The reduction was more pronounced in case of sandy soils. The decrease in soil $\mathrm{pH}$ values were more pronounce by using the fine particle size of $S$ in the investigated soils when compared to the coarse and very coarse $S$ particles. Applying $\mathrm{S}$ up to $2 \%$ level increased values of EC relative to the control treatment. The highest increment was obtained in case of fine particle size of $S$

Egypt. J. Soil Sci. 53, No. 3 (2013) 
when compared to the other S particle size. Application of S up to $2 \%$ level increased soluble sulphate relative to the control treatment. The highest increment was obtained in case of alluvial soils and the increase in soluble sulphate values were high in soil amended with fine particle size of $\mathrm{S}$ compared with the other S particle size. Soil available $\mathrm{P}$ was found to be highly increased due to elemental S application up to $2 \%$ level relative to the control treatment, and the highest increment was obtained in case of fine particle size of $S$ compared with the other S particle size. Levels of the DTPA- extractable heavy metals (Fe and $\mathrm{Mn}$ ) were increased with application of $\mathrm{S}$ to soils, in addition to the highly increment was obtained in case of fine particle size of $\mathrm{S}$ compared with the other S particle size.

\section{References}

Abdel-Fattah, A.A. and Hilal, M.H. (1985) Effect of sulfur application on some properties of Egyptian desert soils. Proc . $2^{\text {nd }}$ Arab Regional Conf . on Sulfur and its Usages $1: 39-53$.

Abdel-Fattah, A. and Hilal, M.H. (1984) Effect of sulphur application on the availability of some micronutrients in different Egyptian soils. Proc. $2^{\text {nd }}$ National Conference on the Problems of Land Degradation, Cairo, Egypt, Nov. 19 - 22.

Abdel-Fattah, A., Hilal, M. H. and Saber, M. (1984) Effect of sulphur application on $\mathrm{pH}, \mathrm{EC}$ and availability of phosphorus in different Egyptian soil. Proc. $2^{\text {nd }}$ National Conference on the Problems of Land Degradation, Cairo, Egypt (Nov. 19-22).

Abdel-Fattah, A., Rasheed, M.A. and Shafei, A.M. (2005) Phosphorus availability as Influenced by different application rates of elemental sulphur to soils. Egypt. J. Soil Sci. 45 (2): 199 - 208.

Admaczyk Winiarska, Z., Krol, M. and Kobus, J. (1975) Microbial oxidation of elemental sulphur in brown soil. Plant and Soil 43: 95 - 100.

Ali, O. M. (1974) K supplying power of the soil of Egypt. Ph.D. Thesis, Fac. of Agric., Al-Azhar Univ., Egypt.

Ali, O. M., El-Sikhry, E. M., El-Shal, A. A. and Ali, A. A. (1991 b) Effect of sulphur, phosphorus and time of irrigation on yield and chemical composition of wheat under calcareous soil conditions. $2^{\text {nd }}$ African Soil Sci. Soc. Conf. 4-10 November, pp. 347354, Cairo, Egypt,

Ammal, U. B. , Mathan, K. K. and Mahimairaja, S. (2000) Oxidation of elemental sulphur in red non - calcareous (Typic Haplustalf) soil. Madras Agric. J. 87: 257 260.

Anter, F. and Hilal, M. H. (1981) Effect of saline water on phosphate movement and availability in the presence of $\mathrm{CaCO}_{3}$. Egypt. J. Soil Sci. 21: $135-142$. 
Atia, R.H. (2005) Effect of sulphur, phosphorus and nitrogen addition on soybean productivity and quality. 1. Agric .Sci. Mansoura Univ. 30 (1): $711-722$.

Balwan, S., Duhan, B.S., Yadav, H.D. and Kumar, V. (2006) Effect of different factors on oxidation of elemental sulphur in soils of Haryana. Haryana Agric. Univ. J. Res. 36: $31-34$

Beheiry, G.G., Nadia, F. E., Soliman, A.A. and El-Bagouri, I.H. (1997) Accumulative and residual effect of natural amendments on chemical properties of some desert soil under saline water irrigation. International Symposium of Salt Affected Soil, pp. 395 405, Jordan Univ. Sci. \& Technol. Jordan, Irbid.

Beheiry, G. Gh. S. (1993) Role of soil amendments in a virgin desert soil and their effect on plant nutrition. Ph. D .Thesis, Fac. Agric, Ain Shams Univ., Egypt.

Bole, J. B. (1986) Amelioration of a calcareous solonetzic soil by irrigation, deep ripping and acidification with elemental sulfur. Can. J. Soil Sci. 66: 347 - 356.

Burns, G.R. (1984) Oxidation of sulphur in soils. The Sulphur Institute, Technical Bulletin No. 13.

Caldwell, A.C. (1967) The oxidation of elemental sulphur in soil. Soil and Fer. 30: 73-85.

Dawood, F.A., Al-Omar, S.M. and Murtatha, N. (1985) High levels of sulphur effecting availability of some micronutrients in calcareous soils. In Proc. Sec. Reg. Conf. On sulphur and Its Msage in Arab Countries, Riyadh, 2 - 5 March 1985, Saudi Arabia 1: 55-68.

Diab, M., Zaid, M.S., Noval, M.A. and El-Masry, A.A. (1995) Effect of some soil amendments on the availability of nutrients in alkali and saline soils. Al-Azhar $J$. Agric. Res. 22: 279 - 292.

El-Fayoumy, M.E. and El-Gamal, A.M. (1998) Effect of sulphur application rates on nutrients availability, uptake and potato quality and yield in calcareous soil. Egypt. $J$. Soil Sci. 38 (1-4): 271 - 286.

El-Gamal, A.M., Diab, G.S. and Abdel - Naby, H. M. (1990) Effect of sulphur application on potato crop. J. Agric. Sci. Mansoura Univ. 15: 2159-2168.

El-Ghanam, M.M., El-Raies, S. A. and Ahmed, W.E. (1999) Effect of sulfur and saline drainage water application under different incubation periods on some soil chemical properties. Annals of Agric. Sci., Moshtohor 37 (3): 2117 - 2125.

El-Sersawy, M.M., Abd El-Ghani, B.F., Hashem, F.A. and Khalil, K.W. (1992) Effect of manuring and $\mathrm{P}$ fertilization on wadi sudr soil environment and cowpea production . Egypt. J. Appl. Sci. 7: 646-668.

Eriksen, J. (2009) Soil sulfur cycling in temperate agricultural systems. Advance Agronomy 102: 55-89. 
Hammad, S.A., El-Hamdi, Kh.H., Abou El-Soud, M.A. and El-Sanat, G.M.A. (2007) Effect of some soil amendments application on the productivity of wheat and soybean, mobility and availability of nitrogen . J. Agric. Sci. Mansoura Univ. 32 (9): $7953-7965$.

Hilal, M.H. and Abd-Elfattah, A. (1987) Effect of $\mathrm{CaCO}_{3}$ and clay content of alkaline soils in their response to added sulphur. Sulfur in Agriculture 11: 15-19.

Ismail, A.I. (1997) Effect of some soil amendments and boron content of water on soil properties and the biochemical componemts of sugar beet yield under irrigation with saline water. Ph. D. Thesis, Fac. of Agric., Moshtohor, Zagazig Univ.

Itanna, F. (2005) Sulfur distribution in five Ethiopian Rift Valley soils under humid and semi - aird climate . Journal of Arid Environments 62: 597 - 612 .

Jalilehvand, F. (2006) Sulfur: not a silent element any more. Chemical Society Review. 35: $1268-1256$.

Janzen, H.H. and Bettany, J.R. (1987 b) The effect of temperature and water potential on sulfur oxidation in soil. Soil Sci . 144: $81-89$.

Janzen, H. H. and Bettany , J . R. (1987a) Measurement of sulfur oxidation in soils . Soil Sci. 143: $444-452$.

Kalbasi, M., Filsoof, F . and Nejad, Y. R. (1988) Effect of sulphur treatments on yield and uptake of Fe, Zn and Mn by Corn, Sorghum and Soybeans . J. Plant Nutr. 11 $(6-11): 1353-1360$.

Khater, A. M. (1981) A study of sulphur and petroleum by products as efficient materials affecting the availability of certain nutrients in soil. M. Sc. Thesis, Fac. Agric., Ain Shams Univ.

Lee, A., Watkinson, J. H. and Nguyen, M . L. (1990) Oxidation of elemental sulphur by thiobacilli in soils from New Zealand. Proceedings Middle East Sulphur Symposium, 12 - 16. February, Cairo, Egypt, $109-124$.

Mary, A.R. and Hao, W. (1995) An evaluation of composts for land scape soil amendments Ohio Agricultural Research and Development Center / Ohio State University Extension / Horticuture and Crop Science.

McCready, R.G .and Krouse, H.R. (1982) Sulphur isotope fractionation during the oxidation of elemental sulphur by thiobacilli in a solonetzic soil. Can. J. Soil Sci. 62 $105-110$.

Modaihsh, A.S., Al-Mustafa, W.A. and Metwally, A.I. (1989) Effect of elemental sulphur on chemical changes and nutrient availability in calcareous soils. Plant and Soil 116: 95 - 101 .

Morris, R.J. (1992) The growing need for sulfur fertilizers in latin America and the Caribbean . Inter. Fert. Assoc. Regional Conf. Latin America and Caribbean, 8 - 10 July, (c.f. Soil \& Fert. 65, 10116, 1993 ). 
Morsy, M . Y . (1985) Effect of sulfur on alluvial and calcareous soils . Proc . $Z^{\text {nd }}$ Arab Regional Conf. on Sulfur and its Usages 1: 185-199.

Mostafa, M.A., El-Gala, A.M., Wassif, M., El Maghraby, S.E. and Hilal, M.H. (1990) Distribation of some micronutrients through a calcareous soil columns under sulphur and saline water application. Proceedings Middle East Sulphur Symposium 12 - 16 February, Cairo, Egypt, pp $263-276$.

Nasseem, M.G. and Nasrallah, A.K. (1981) The effect of sulphur on the response of cotton on area under alkali soil conditions in pot experiments . Plant and Soil 62: 255 -263 .

Page, A.L., Miller, R. H. and Keeney, D. R. (1982) "Methods of Soil Analysis part 2: Chemical and Microbiolgical Properties”. Am. Soc. Agion. ,Madison ,Wisconsin, USA .

Reda, M. and Modaihsh, A. S. (1990) Gypsum formation in sulphur treated calcareous soils . Arab Gulf J. Scient. Res. 8: $79-91$.

Ryan, J., Miyamoto, S. and Stroehlein, J.L. (1974) Solubility of manganese, iron and Zinc as affected by application of sulphuric acid to calcareous soils . Plant and Soil 40: $121-12$.

Sadiq, M. (1985) Use of industrial waste sulphur as soil amendment. In: Proc. Sec. Arab Reg. Conf. on Sulphur and its Usages in the Arab Countries, Riyadh, Saudi Arab ., 1: $142-153$.

Shadfan, S.H. and Hussen, A.A. (1985) Effect of sulphur application on availability of $\mathrm{P}, \mathrm{Fe}, \mathrm{Mn}, \mathrm{Zn}$ and $\mathrm{Cu}$ in selected Saudi soils . In Proc. Sec . Reg. Conf. On Sulphur and its Usage in Arab Countries. Riyadh 2 - 5 March , 1985 Saudi Arabia . 1: $3-24$

Susana, C.B., Johannes, L., Dawit S., Eduardo, F.C. and Luís, R.F.A. (2013) Sulfur forms in organic substrates affecting $\mathrm{S}$ mineralization in soil. Geoderma 200-201: $156-164$.

Velarde, M., Felker, P.and Gardiner, D. (2005) Influence of elemental sulfur , micronutrients, phosphorus, calcium, magnesium and potassium on growth of prosopis alba on high pH soils in Argentina . Journal of Arid Environments 62: 525 539

Yousry, M., El-Leboudi, A. and Khater, A. (1984 b) Effect of sulfur and petroleum by products on soil characteristics . II - Availability of some nutrients in a calcareous soil . Egypt. J. Soil Sci. 124: 195 - 200.

Yousry, M., El-Leboudi, A. and Khater, A. (1984 a) Effect of sulphur and petroleum by-products on soil characteristics. I . Availability of certain nutrients in calcareous soil under intermittent leaching . Egypt. J. Soil Sci. 124: 185-194.

Youssef, R.A. (1997) Studies on nickel and manganese dynamic in the rhizosphere of wheat. In: "Plant Nutrition for Sustainable Food Production and Environment", T. Ando et al. (Ed.), pp. 483 - 486, Kluewer Academic publishers.

Egypt. J. Soil Sci. 53, No. 3 (2013) 
Zhao, F.J., Loke, S.Y., Crosland, A.R. and McGrath, S.P. (1996 a) Method to determine elemental sulphur in soils applied to measure sulphur oxidation . Soil Biol. Boichem. Exeter : Elsevier Sci. 28: 1083 - 1087.

Zhihui, Y., Haneklaus, S., Singh, B. R.and Schnug, E. (2008) Effect of repeated applications of elemental sulfur on microbial population, sulfate concentration, and pH in soils. Communications in Soil Sci. and Plant Analy. 39: $124-140$.

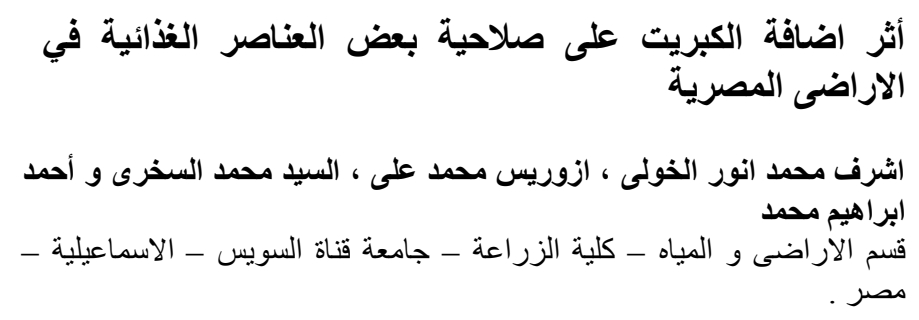

اجريت تجربة لدراسة اثر اضافة الكبريت بمستوياته المختلفة و اقطار حبيباته

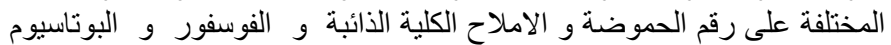

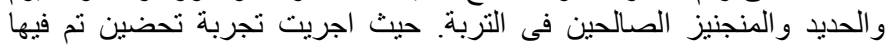

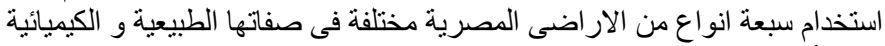

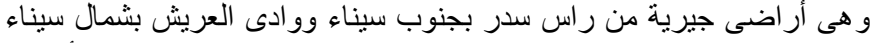

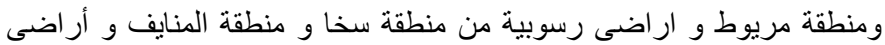

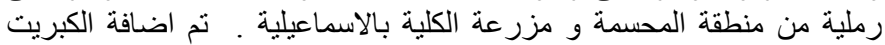

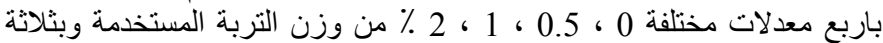

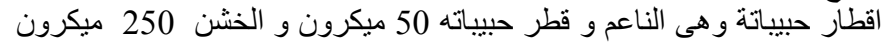

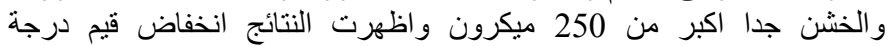

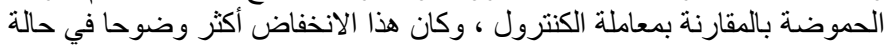

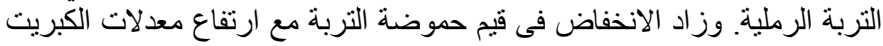

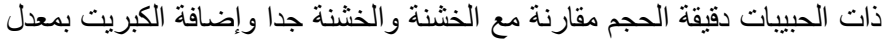

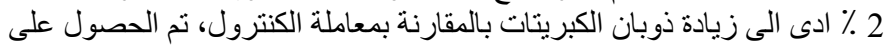

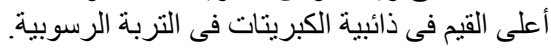

إضافة الكبريت بمعدل 2 ٪ ادى الى زيادة ذوبان الفوسفور الميسر بالمقارنة

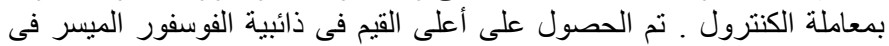

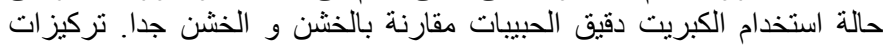

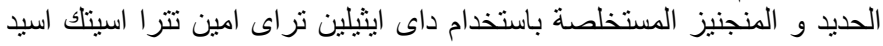

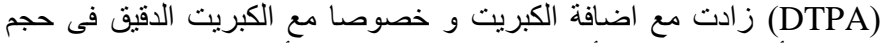

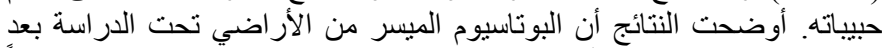

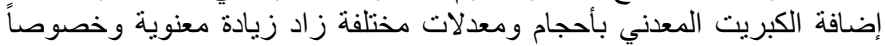
عند معدل 2\% كبريت فى الأر اضي الجيرية بر أس سدر بالمقارنة بالكنترول. 